Münther, V. (in press): The West Greenland basalt formation. Results of a geological reconnaissance around Svartenhuk peninsula. Rapp. Grønlands geol. Unders.

Pedersen, A. K. 1970: En petrologisk undersøgelse af tertiære vulkanske bjergarter fra det nordlige Disko. Unpublished prize dissertation, Univ. of Copenhagen. (Reviewed in Festskrift udgivet af Kobenhavns Universitetet $i$ anledning af Universitetets ärsfest, 1970, 379-383).

Rosenkrantz, A. \& Pulvertaft, T. C. R. 1969: Cretaceous-Tertiary stratigraphy and tectonics in northern West Greenland. Mem. Am. Ass. Petrol. Geol. 12, 883-898.

Steenstrup, K. J. V. 1874: Om de kulförende Dannelser paa öen Disko, Hareöen og Syd-Siden af Nûgssuak's Halvöen i Nord-Grönland. Vidensk. Meddr dansk naturh. Foren. Kbh. 1874, Nr. 3-7, 76-112.

\title{
CONTINUED INVESTIGATIONS OF QUATERNARY DEPOSITS IN THE AREA BOUNDED BY SØNDRE STRØMFJORD, THE INLAND ICE, AND THE SUKKERTOPPEN ICE CAP
}

\section{Norman W. TenBrink}

The 1970 project was a continuation of more general 1969 investigations, some results and the objectives of which were reported by Weidick \& Ten Brink (1969). The objectives of 1970 field work were to: (1) accurately determine altitudes and characteristics of marine limits; (2) complete a collection of marine shells and organic material from emerged marine deposits in order to derive a radiocarbondated delevelling history; (3) obtain cores of sediments from at least three lakes for pollen analysis and C-14 dating of lake-sea isolation times; (4) map in detail some glacial, glaciofluvial, and marine deposits known from 1969 investigations to be particularly important in reconstruction of Holocene events, and (5) conduct a lichenometric survey on young moraines near the Inland Ice in order to estimate ages of the moraines. All the field objectives were achieved, and the results that can be stated before completion of analyses are summarised below.

Marine limits. In general, within the area under consideration, there is a progressive decrease in marine limit with decreasing distance from the present Inland Ice margin. Beginning with the investigated area farthest from the Inland Ice, the marine limit is $120 \pm 10 \mathrm{~m}$ a.s.1. in Aussivit at the head of Itivdleq fjord. (All place names are taken from Danish Geodetic Institute map sheets 66 V.1, 66 V.2 and 67 V.2) The limit is rather well defined in Aussivit by shell-rich silts up to $105 \pm 10 \mathrm{~m}$, and an uppermost strandline $120 \pm 10 \mathrm{~m}$ a.s.l.

In the Angujârtorfik-Angujârtorfiup kûa area, c. $35 \mathrm{~km}$ up Søndre Strømfjord from Aussivit, the marine limit is very difficult to determine precisely, but is definitely greater than $70 \pm 3 \mathrm{~m}$, which is the highest occurrence of unambiguous strandlines, and lower than $134 \pm 10 \mathrm{~m}$, which is the upper limit of terraced sediments filling lower Angujârtorfiup kûa. The local marine limit is tentatively believed to be $115 \pm 10$ $\mathrm{m}$. This judgement is based on the following evidence: (1) $115 \pm 10 \mathrm{~m}$ is the altitude 


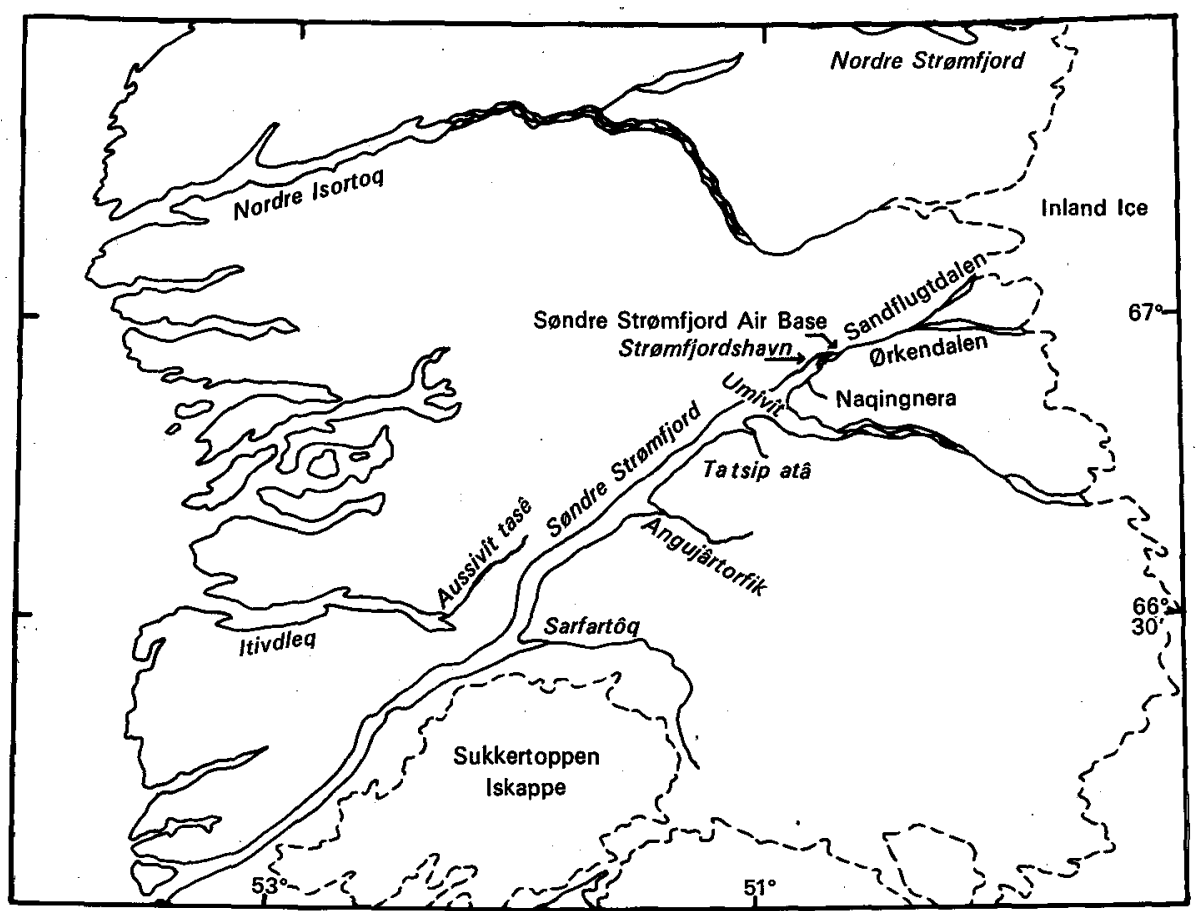

Fig. 3. Sketch map of the Søndre Strømfjord region with locality names.

of the highest strandline-like feature on the north wall of Angujârtorfik, which alternatively may be a nearly horizontal moraine remnant deposited by a glacier lobe in Angujârtorfik, and (2) $115 \pm 10 \mathrm{~m}$ is also the altitude of the highest terrace remnant on the south side of Angujârtorfiup kûa that is probably deltaic. This uppermost "deltaic",terrace occurs at the up-valley extreme of c. $3.5 \mathrm{~km}$ long terraces with gentle gradient, and is joined with massive end moraines up-valley by a steepergradient "outwash",terrace about $0.3 \mathrm{~km}$ long. The relatively steep, short, "outwash", terrace merges with an end moraine $134 \pm 10 \mathrm{~m}$ a.s.l., which is the feature cited earlier as definitely higher than the marine limit.

In Tatsip atâ, c. $20 \mathrm{~km}$ up Søndre Strømfjord from Angujârtorfik, the marine limit is also difficult to establish but is definitely greater than $85 \pm 5 \mathrm{~m}$ (altitude of ice-push ridges above $75 \pm 2 \mathrm{~m}$ highest strandlines), and less than $110 \pm 10 \mathrm{~m}$ (altitude of moraine-outwash terrace junction). The marine limit in the Tatsip atâ area is tentatively believed to be $100 \pm 10 \mathrm{~m}$ as that is the up-valley limit of low-gradient terraces that are probably deltaic. The deposits and morphologic features at the head og Tatsip atâ that provide the evidence for the above limits are entirely analogous to those described from Angujârtorfik; massive moraines a few kilometres up-valley from the head of the bay are confluent down-valley with relatively short, steep, out- 
wash terraces that transitionally merge with lower-gradient "deltaic", terraces, and finally become definitely deltaic near the head of the bay.

Near the head of Søndre Strømfjord, a former marine level of $65-70 \mathrm{~m}$ a.s.1. is clearly indicated. A wave-cut bench $64-66 \mathrm{~m}$ a.s.l. and lower strandlines are locally developed on lateral moraines, drift, and even to a minor degree on bedrock, in the following localities: (1) south, east, and north shores of Umîvit; (2) south-east shore of Søndre Strømfjord across from Strømfjordshavn below the area called Naqingnera; (3) north-west shore of Søndre Strømfjord between Strømfjordshavn and Tarajornitsup nûgssua, and (4) a few hundred metres north-west of Strømfjordshavn, where remnants of a 60-66 m terrace may questionably be discerned on massive drift despite extensive gravel mining and construction. In these same areas, perched boulders and fine-grained drift on fjord walls have a poorly defined lower limit 75-85 $\mathrm{m}$ a.s.1. Thus, evidence of a marine level c. $65 \mathrm{~m}$ a.s.l. is strongly developed on deposits of the last glacial advance and probably corresponds to the 65-70 m marine limit from Umîvît at least as far inland as Strømfjordshavn.

In the same area as that just described, a few poorly preserved and genetically indefinite "benches" also occur on drift and bedrock about $140 \pm 20 \mathrm{~m}$ a.s.l., and similar features were found in Tatsip atâ. Although alternative explanations are equally plausible, and the idea cannot be proved, the $140 \pm 20 \mathrm{~m}$ "benches", may represent older marine features, formed during a retreat of the Inland Ice before the glacial advance that was clearly contemporaneous with $65-70 \mathrm{~m}$ relative sea level.

Proceeding to the inland limit of marine deposits, in the area near Søndre Strømfjord Air Base, the marine limit decreases to less than $45 \mathrm{~m}$ (lowest moraines unaffected by wave action), but is definitely greater than $35 \mathrm{~m}$ (highest foreset deltaic beds with marine shells). Thus, local marine limit is $40 \pm 5 \mathrm{~m}$. Extensive terraces of "fluvial" sediments over marine sediments, occurring in the mouths of Ørkendalen and Sandflugtdalen at $40 \pm 5 \mathrm{~m}$, were undoubtedly graded to a former sea level, and therefore provide additional evidence of a $c .40 \mathrm{~m}$ marine limit. Evidence analogous to that near Søndre Strømfjord Air Base indicates that the marine limit is also $40 \pm 5 \mathrm{~m}$ at the inland limit of marine deposits $c .18 \mathrm{~km}$ up-valley from the head of Umîvit.

Samples for C-14 dating marine levels. Thirty-two samples (29 shell samples and 3 peat samples) were collected during 1970 . These, together with twenty-two samples collected in 1969, span an altitude range from 0.5 to $105 \pm 10 \mathrm{~m}$, and should date former sea levels from $5 \pm 1$ to $120 \pm 10 \mathrm{~m}$. Twenty-one samples have already been submitted for C-14 dating, and at least six more from lake sediment cores will soon be submitted.

Lake-sediment cores. Cores were obtained from three lakes: one on marine deposits $51 \pm 3 \mathrm{~m}$ a.s.l. near the south shore of Umîvit; one on marine deposits $38 \pm 2 \mathrm{~m}$ a.s.l. near the Air Base; and, one on outwash sediments $48 \pm 2 \mathrm{~m}$ a.s.l. near the west base of Keglen about $7.0 \mathrm{~km}$ north-east of the Air Base. At least two "complete". 
cores were taken from each lake, and all contained about $1.5 \mathrm{~m}$ of organic-rich lacustrine mud underlain by marine or out-wash sediments. Palynological analyses are being made by Dr. Matsuo Tsukada of the University of Washington, Seattle, and should be completed by the spring of 1971 .

Glacial deposits. The mapping of glacial and related deposits cannot be reported here, and is still in progress through interpretation of new air photographs covering the entire area reconnoitred by helicopter in 1969 . When completed, it is hoped that the maps will permit correlation of ice-margin deposits throughout the area studied by Weidick \& Ten Brink (1969), and by Sugden (1969).

In general, it appears that several stades or sub-stades during Holocene retreat of the Inland Ice are represented by well-developed zones of moraines and kame terraces, which can be dated by their relations to former sea levels varying from $c .120$ to $40 \mathrm{~m}$ a.s.l. (cf. Weidick, 1968). In addition, two ice-margin positions inland from marine limit will be dated locally by organic material from former ice-dammed lakes.

Lichen measurements. A lichenometric survey of moraines was made near the present ice margin at the heads of Ørkendalen and Sandflugtdalen, and it may permit age estimates for some recent ice-margin positions. The results of the survey are being interpreted with the aid of Dr. Roland Beschel, Queen's University, Kingston, Ontario, one of whose "lichen stations", (Beschel, 1961) was remeasured by the the writer. Unfortunately, it appears that severe micro-climatic variations near the Inland Ice may be a great obstacle to interpretation of the lichen measurements.

$\mathrm{C}^{14}$-dates on post-glacial marine shells

Post-glacial marine shells collected from three localities near the head of Søndre Strømfjord were dated during 1970 by Henrik Tauber, Carbon-14 Dating Laboratory, National Museum, Copenhagen. The following results were obtained:

$$
6330 \pm 120 \text { years B.P. }
$$

GGU 119501 and $119502 ; \mathrm{K}-1720$. c. $6 \mathrm{~km}$ upstream from the head of Umîvit on north side of river $\left(66^{\circ} 52^{\prime} 24^{\prime \prime} \mathrm{N}, 51^{\circ} 37^{\prime} 40^{\prime \prime} \mathrm{W}\right)$. Shell species: Mytilus edulis, Balanus sp., Hiatella arctica, Macoma calcarea.

The shells were collected from the surface of a marine terrace $37 \pm 4 \mathrm{~m}$ a.s.l., and are considered to date a relative sea level $37 \pm 4 \mathrm{~m}$ above present sea level as well as the minimum time of local deglaciation.

$$
6140 \pm 120 \text { years B.P. }
$$

GGU 119506; K-1721. Locality the same as sample K-1720. Shell species: Balanus sp.

The shells were collected from immediately below the surface of a marine terrace and from the surface of bedrock to which they were still attached in life-like position 19-20 $\mathrm{m}$ a.s.1., and are considered to date a relative sea level $19-20 \mathrm{~m}$ above present sea level. 
$6060 \pm 120$ years B.P.

GGU 119524; K-1722. South-east shore of the head of Umîvit $\left(66^{\circ} 49^{\prime} 20^{\prime \prime} \mathrm{N}, 50^{\circ}\right.$ 45'30" W). Shell species: Mytilus edulis, Balanus sp., Hiatella arctica, Mya truncata, Macoma calcarea, Cardium sp.

The shells were collected from immediately below the surface of a marine terrace and from the surface of bedrock to which Balanus were still attached in life-like position 19-20 m a.s.l., and are considered to date a relative sea level $19-20 \mathrm{~m}$ above present sea level.

\section{References}

Beschel, R. 1961 : Dating rock surfaces by lichen growth and its application to glaciology and physiography (lichenometry). In Raasch, G. (editor) Geology of the Arctic 2, 1044-1062. Toronto U.P.

Sugden, D. E. 1969: Preliminary report of the Aberdeen University West Greenland Expedition 1968. Scott. geogr. Mag. 85, 105-108.

Weidick, A. 1968: Observations on some Holocene glacier fluctuations in West Greenland. Bull. Gronlands geol. Unders. 73 (also Meddr Gronland 165, 6) $202 \mathrm{pp}$.

Weidick, A. \& Ten Brink, N. W. 1969 : Quaternary deposits between the Sukkertoppen ice cap and Nordre Strømfjord. Rapp. Grønlands geol. Unders. 28, 23-25.

\section{FIELD WORK IN THE FISKENÆSSET AREA}

\section{F. Kalsbeek}

In 1969 GGU's base camp was moved from Mellembygden to Midgaard, some 15 km NNE of Fiskenæsset. In the summer of 1970 the systematic mapping of the Fiskenæsset area started. The following geologists took part in the mapping: L. Skov Andersen (Copenhagen), T. Frisch (Edmonton), A. M. Hopgood (St. Andrews), T. C. R. Pulvertaft (GGU), G. Rivalenti (Modena), J. R. Tomas (Prague), B. J. Walton (Portsmouth), H. R. Williams (Exeter) and B. F. Windley (Leicester). A special study of the sapphirine localities known in the area was made by R. K. Herd (Leicester). The field groups were organised much as in earlier years. Every geologist had an assistant. Transport was supplied by two Bell $47 \mathrm{~J}$ helicopters and two GGU cutters. Most of the practical arrangements were made by Ib Olsen of GGU.

Most of the area covered this summer, roughly situated between Frederikshåb Isblink and Fiskenæsset $\left(62^{\circ} 40^{\prime}-63^{\circ} 10^{\prime} \mathrm{N}\right)$, consists of fairly uniform gneisses which locally are slightly banded and which contain bands and lenses of amphibolite. 